\title{
Assessing antibiotic sorption in soil: a literature review and new case studies on sulfonamides and macrolides
}

\author{
Stacia R Wegst-Uhrich ${ }^{1}$ Divina AG Navarro ${ }^{1,2}$, Lisa Zimmerman ${ }^{1}$ and Diana S Aga ${ }^{1 *}$
}

\begin{abstract}
The increased use of veterinary antibiotics in modern agriculture for therapeutic uses and growth promotion has raised concern regarding the environmental impacts of antibiotic residues in soil and water. The mobility and transport of antibiotics in the environment depends on their sorption behavior, which is typically predicted by extrapolating from an experimentally determined soil-water distribution coefficient $\left(K_{d}\right)$. Accurate determination of $K_{d}$ values is important in order to better predict the environmental fate of antibiotics. In this paper, we examine different analytical approaches in assessing $K_{d}$ of two major classes of veterinary antibiotics (sulfonamides and macrolides) and compare the existing literature data with experimental data obtained in our laboratory. While environmental parameters such as soil pH and organic matter content are the most significant factors that affect the sorption of antibiotics in soil, it is important to consider the concentrations used, the analytical method employed, and the transformations that can occur when determining $K_{d}$ values. Application of solid phase extraction and liquid chromatography/mass spectrometry can facilitate accurate determination of $K_{d}$ at environmentally relevant concentrations. Because the bioavailability of antibiotics in soil depends on their sorption behavior, it is important to examine current practices in assessing their mobility in soil.
\end{abstract}

Keywords: Veterinary pharmaceuticals, Antibiotics, Antimicrobials, Sulfamethazine, Tylosin, Partition coefficient, Sorption, Mobility, Degradation, Transformation

\section{Introduction}

Veterinary pharmaceuticals (VPs) are physiologically active compounds that are used to protect animals against parasites, prevent bacterial infections, and growth promotion [1-6]. Antibiotics, their synthetic analogues, and synthetically produced antimicrobials are introduced in both therapeutic and medical dosages to the animals through medicated feeds, injections, and external application [1]. Most animals do not absorb these compounds completely; hence antibiotics are excreted in urine and feces as parent compounds, and in mixtures with their conjugated metabolites and oxidation/hydrolysis products [1,3-8].

The presence of antibiotic residues in animal manure that are land-applied to agricultural lands can contaminate water and soil [9-11]. Consequently, changes in the

\footnotetext{
* Correspondence: dianaaga@buffalo.edu

${ }^{1}$ Department of Chemistry, University at Buffalo, State University of New York, Buffalo, NY 14260, USA

Full list of author information is available at the end of the article
}

soil microbial population can occur; the microorganisms' ability to degrade contaminants and their role in chemical cycles, such as nitrification, may be affected significantly $[5,7,12-14]$. Persistent antibiotics can accumulate in the top layers of soil, may leach to the groundwater, or can be transported to surface waters $[1,15,16]$. Sulfonamide antibiotics, the first broad spectrum antibacterial medications [17], are relatively persistent in the environment and do not sorb strongly to soil. Thus, sulfonamides have been detected in surface water, ground water, soil pore water [18-20], and drinking water [21] that have been impacted by agricultural and human activities.

A common parameter used to predict the transport behavior of organic contaminants in soil is the soil-water partition coefficient, $K_{d}$. The $K_{d}$ values can be directly determined experimentally, or derived indirectly from the octanol-water partition coefficients $\left(\mathrm{K}_{\mathrm{ow}}\right)$ or by computational modeling using free energy calculations. Because
(C) Chemistry Central

(c) 2014 Wegst-Uhrich et al.; licensee Chemistry Central Ltd. This is an open access article distributed under the terms of the Creative Commons Attribution License (http://creativecommons.org/licenses/by/2.0), which permits unrestricted use, distribution, and reproduction in any medium, provided the original work is properly cited. 
the sorption properties of antibiotics affect their mobility and ecotoxicology, it is important to recognize that different $K_{d}$ measurements may provide varying results that could potentially lead to large errors in environmental models that are used in risk assessment.

The fate and transport of antibiotics in the environment depend on the underlying physical properties of the compound such as water solubility, lipophilicity, volatility, and sorption potential. Soil can act as potential sink, and thus sorption of antibiotics in the solid phase can reduce their mobility, reactivity, and bioavailability for microbial degradation [22]. In addition, soil properties such as organic carbon content, ionic strength, clay content, texture, and $\mathrm{pH}$ can alter sorption mechanisms involved, and the extent of sorption of antibiotics [23]. The assumption that sorption occurs solely through hydrophobic partitioning to soil organic matter (OM) is inappropriate for antibiotics with ionizable groups, when electrostatic interactions and hydrogen bonding become significant [1].

The purpose of this paper is to provide a review of the different ways that $K_{d}$ values are measured, and demonstrate how the analytical differences may affect the prediction of the fate and transport of antibiotics in the environment. Specifically, this review will focus on two of the most used classes of antibiotics: sulfonamides and macrolides. Within these classes, sulfamethazine, tylosin, and erythromycin are examined due to their wide use in animal related practices, and their variable sorption properties $[1,24]$.

\section{Review}

Octanol-water partition coefficient $\left(\mathrm{K}_{\mathrm{ow}}\right)$ and octanolwater distribution ratio $\left(D_{\text {ow }}\right)$

Antibiotic mobility in soil has been traditionally estimated using the octanol-water partition coefficient $\left(\mathrm{K}_{\mathrm{ow}}\right)$ :

$$
K_{\text {ow }}=\frac{[\text { Solute }]_{\text {octanol }}}{[\text { Solute }]_{\text {water }}}
$$

However, $\mathrm{K}_{\mathrm{ow}}$ only reflects hydrophobic interactions and does not accurately account for electrostatic interactions, surface complexation, hydrogen bonding, cationexchange, or bridging that may vary significantly with changes in $\mathrm{pH}, \mathrm{OM}$, and ionic strength [1]. While the use of $\mathrm{K}_{\mathrm{ow}}$ in predicting soil sorption behavior of nonpolar compounds works fairly well, the application of $\mathrm{K}_{\mathrm{ow}}$ for polar or ionizable compounds, such as many antibiotics, may be inaccurate. Additionally, the variety of environmental factors (such as soil properties) that can affect sorption will complicate the modeling efforts to predict sorption and mobility of antibiotics. For example, OM may block interlayer sites of clay minerals
[25], but such phenomenon is not accounted for by $\mathrm{K}_{\mathrm{ow}}$ values. Thus simply using $\mathrm{K}_{\mathrm{ow}}$ will result in incorrect assessment of antibiotic fate and transport in the environment.

The $\mathrm{pH}$ dependent octanol-water distribution ratio $\mathrm{D}_{\text {ow }}$, can be used to avoid variations in $\mathrm{K}_{\mathrm{ow}}$ values resulting from changes in $\mathrm{pH}$. The $\mathrm{D}_{\mathrm{ow}}$ value considers hydrophobicity and ionogenicity, and is a combination of the $\mathrm{K}_{\mathrm{ow}}$ (of the neutral compound) and the $\mathrm{pK}_{\mathrm{a}}$, in which the transfer of both neutral and ionized species between the aqueous and immiscible phase is accounted for [26]. The $\mathrm{D}_{\text {ow }}$ value does not consider hydrophobicity as the sole governing factor that dictates partitioning of neutral compounds, but also accounts for the transfer of ion pairs and free ions from aqueous to the organic layer $[27,28]$ :

$$
D_{\text {ow }}=\frac{[\text { nonionized }+ \text { ionized species }]_{\text {octanol }}}{[\text { nonionized }+ \text { ionized species }]_{\text {water }}}
$$

A relationship between $\log \mathrm{K}_{\mathrm{ow}}$ and $\log \mathrm{D}_{\mathrm{ow}}$ can be derived for both acidic and basic compounds [29]. For sulfamethazine, $K_{o w}$ values between 1.042 and 3.750 are reported, while $\mathrm{D}_{\text {ow }}$ values between 0.427 and 1.950 are reported (determined at $\mathrm{pH}$ values of 4-8). These $\mathrm{K}_{\mathrm{ow}}$ and $\mathrm{D}_{\mathrm{ow}}$ values were calculated using Advanced Chemistry Development (ACD/Labs) Software V11.02 ( 1994-2012 ACD/Labs). Notably, these values fall in the lower part of the wide range of $K_{d}$ values $(0.23-30 \mathrm{~L} / \mathrm{kg}$ ) obtained experimentally, as reported from literature (Table 1).

\section{The $K_{d}$ partition coefficient}

The soil-water partition coefficient $\left(\mathrm{K}_{\mathrm{d}}\right)$ is used to describe the sorption potential of pollutants and the extent that they will move into the ground or surface waters. Using $\mathrm{K}_{\mathrm{d}}$ instead of $\mathrm{K}_{\mathrm{ow}}$ demonstrates sorption behavior with respect to the soil media of interest, and data extrapolation from the octanol to soil matrices is eliminated. The $K_{d}$ value is the ratio between the concentration of the compound in soil $\left(\mathrm{C}_{\mathrm{s}}\right)$ [total concentration, including sorbed transformation products] to the concentration of the dissolved compound in water $\left(\mathrm{C}_{\mathrm{w}}\right)[1]$ :

$$
K_{d}=\frac{C_{s}}{C_{w}}
$$

In the experimental determination of $K_{d}$ values, it is important to accurately measure the concentrations of the compounds at environmentally relevant levels for both the water and soil components to assure mass balance. $K_{d}$ is typically determined one of two ways: (1) column displacement studies in which determination occurs from a breakthrough curve at a single location, or (2) batch sorption experiments in which multiple concentrations are used to construct isotherms by plotting $\mathrm{C}_{\mathrm{s}}$ versus $\mathrm{C}_{\mathrm{w}}$. 
Table 1 Sorption coefficients of sulfamethazine

\begin{tabular}{|c|c|c|c|c|}
\hline Soil type & $\mathrm{K}_{\mathrm{d}}(\mathrm{L} / \mathrm{kg})$ & Concentration range used & Measurement technique & Reference \\
\hline \multirow[t]{7}{*}{ Sandy loam } & $0.27-0.77$ & $1.5,3.5,7.5,10,15 \mathrm{ppm}$ & HPLC-UV $(\lambda=275 \mathrm{~nm})$ & [34] \\
\hline & $0.23-1.22$ & $0.3-20$ ppm & HPLC-UV $(\lambda=254 \mathrm{~nm})$ & [33] \\
\hline & $9.8-22$ & $0,0.25,0.50,1.0,2.5,4.0 \mathrm{ppm}$ & $\operatorname{HPLC-UV}(\lambda=275 \mathrm{~nm})$ & {$[32]$} \\
\hline & $0.95-19.53$ & $17.7,35.4,53.1,70.8,88.5 \mathrm{ppb}$ & Liquid scintillation counting & ED \\
\hline & & & (LSC) with ${ }^{14} \mathrm{C}-\mathrm{SMZ}$ & Method 1 \\
\hline & $1.0-7.52$ & $1,3,10,20,30,50,100,300 \mathrm{ppb}$ & LSC with ${ }^{14} \mathrm{C}-\mathrm{SMZ}$ & ED \\
\hline & & & & Method 1 \\
\hline \multirow[t]{2}{*}{ Clay loam } & 2.88 & $1.5,3.5,7.5,10,15$ ppm & $\operatorname{HPLC-UV}(\lambda=275 \mathrm{~nm})$ & [34] \\
\hline & $16.55 \pm 1.41$ & $0.012,0.122,1.219 \mathrm{ppm}$ & LSC with ${ }^{14} \mathrm{C}-\mathrm{SMZ}$ & [31] \\
\hline \multirow[t]{7}{*}{ Loam } & $1.05-3.91$ & $0.3-20$ ppm & $\operatorname{HPLC-UV}(\lambda=254 \mathrm{~nm})$ & [33] \\
\hline & $3.1-17$ & $0,0.25,0.50,1.0,2.5,4.0 \mathrm{ppm}$ & $\operatorname{HPLC-UV}(\lambda=275 \mathrm{~nm})$ & {$[32]$} \\
\hline & $2.83-22.28$ & $17.7,35.4,53.1,70.8,88.5 \mathrm{ppb}$ & Liquid scintillation counting & ED \\
\hline & & & (LSC) with ${ }^{14} \mathrm{C}-\mathrm{SMZ}$ & Method 1 \\
\hline & $0.9-18.2$ & $1,3,10,20,30$ & LSC with ${ }^{14} \mathrm{C}-\mathrm{SMZ}$ & ED \\
\hline & & $50,100,300 \mathrm{ppb}$ & & Method 1 \\
\hline & $17.10 \pm 1.66$ & $0.012,0.122,1.219 \mathrm{ppm}$ & LSC with ${ }^{14} \mathrm{C}-\mathrm{SMZ}$ & [31] \\
\hline Silty clay loam & $18.58 \pm 2.29$ & $0.012,0.122,1.219 \mathrm{ppm}$ & LSC with ${ }^{14} \mathrm{C}-\mathrm{SMZ}$ & [31] \\
\hline \multirow[t]{4}{*}{ Silt loam } & $0.82-2.12$ & $1.5,3.5,7.5,10,15 \mathrm{ppm}$ & $\operatorname{HPLC-UV}(\lambda=275 \mathrm{~nm})$ & {$[34]$} \\
\hline & $0.66-6.73$ & $2.5-50 \mu \mathrm{M}$ & $\operatorname{HPLC-UV}(\lambda=254 \mathrm{~nm})$ & {$[30]$} \\
\hline & & & LSC with ${ }^{14} \mathrm{C}-\mathrm{SMZ}$ & \\
\hline & $206.18 \pm 12.09$ & $0.012,0.122,1.219 \mathrm{ppm}$ & LSC with ${ }^{14} \mathrm{C}-\mathrm{SMZ}$ & {$[31]$} \\
\hline Loamy sand & $2.3-30$ & $0,0.25,0.50,1.0,2.5,4.0 \mathrm{ppm}$ & HPLC-UV $(\lambda=275 \mathrm{~nm})$ & {$[32]$} \\
\hline Sand & $7.52 \pm 0.09$ & $0.012,0.122,1.219 \mathrm{ppm}$ & LSC with ${ }^{14} \mathrm{C}-\mathrm{SMZ}$ & {$[31]$} \\
\hline
\end{tabular}

Note: Results are soil dependent. ED: experimentally determined. Methodology can be found in the additional files. $\mathrm{K}_{\mathrm{ow}}$ of sulfamethazine ranges from 1.042-3.750. $\mathrm{K}_{\text {ow }}$ values calculated using Advanced Chemistry Development (ACD/Labs) Software V11.02 (৫) 1994-2012 ACD/Labs).

Experimentally determined $\mathrm{K}_{\mathrm{d}}$ values reported in the literature for a particular compound are highly variable even for the same soil type and environmental conditions. For example, Tables 1 and 2 list $K_{d}$ values for sulfamethazine, a sulfonamide [30-34] and tylosin, a macrolide [2,6,25,35-38], respectively. Corresponding plots were drawn in Figure 1 to clearly demonstrate the wide range of their $K_{d}$ values reported. For the same type of soil, $\mathrm{K}_{\mathrm{d}}$ values appear to vary widely depending on the concentration ranges used to determine $\mathrm{K}_{\mathrm{d}}$.

In general, $K_{d}$ values have been obtained using high concentrations (in the parts per million range) of antibiotics that are not environmentally relevant. High concentrations are used to enable detection of the desorbed portion without sample pre-concentration. However, the use of high concentrations of antibiotics for sorption experiments can result in anomalies when the $\mathrm{K}_{\mathrm{d}}$ value is concentration-dependent and exhibits nonlinearity. For example, the $K_{d}$ value for sulfachloropyridazine $\left(\mathrm{pk}_{\mathrm{a}}=1.88,5.90\right)$ was determined in sandy loam (pH 6.0-7.5 and 6.6, respectively) at 1-10 ppb to be $0.9 \mathrm{~L} / \mathrm{kg}$, while when determined at $1.5 \mathrm{ppm}$ the $\mathrm{K}_{\mathrm{d}}$ value was $8.1 \mathrm{~L} / \mathrm{kg}$. These discrepancies in the $\mathrm{K}_{\mathrm{d}}$ values pose differences in predicting the fate of sulfachloropyridazine; it implies that at lower concentrations, sulfachloropyridazine is considered to have high mobility under the pesticide mobility classification $[6,19]$, while at higher concentrations sulfachloropyridazine has low mobility $[6,39]$.

\section{The freundlich sorption constant, $\mathrm{K}_{\mathrm{f}}$ :}

Because sorption coefficients are not always the same at all aqueous concentrations, linear plots are not always observed. In the case of tylosin, non-linearity has been previously reported [40,41], and therefore all original data will be presented as both $K_{d}$ and $K_{f}$ values. The Freundlich constant (sorption coefficient) $K_{f}$ provides a better estimate of partitioning:

$$
K_{f}={\frac{C_{s}}{C_{w}}}^{1-n}
$$

where $n$, the Freundlich exponent, is a measure of the isotherm nonlinearity. A plot of $\log C_{s}$ vs. $\log C_{w}$ gives a 
Table 2 Sorption coefficients of tylosin

\begin{tabular}{|c|c|c|c|c|}
\hline Soil Type & $\mathrm{K}_{\mathrm{d}}(\mathrm{L} / \mathrm{kg})$ & Concentration range used & Measurement technique & Reference \\
\hline \multirow[t]{9}{*}{ Sandy Loam } & $58.1-148.0$ & $500 \mathrm{ppb}$ & LC-MS & [37] \\
\hline & & & LC-fluorescence & \\
\hline & 92 & 1000 ppm & ELISA & [35] \\
\hline & $101.02-13961.00$ & $10,100,200,1000 \mathrm{ppb}$ & HPLC-MS & ED \\
\hline & & & (ion trap) & Method 2 \\
\hline & $6737-33871$ & $1,5,10,100,200,500,1000 \mathrm{ppb}$ & HPLC-MS/MS & ED \\
\hline & & & & Method 3 \\
\hline & 42 & $5 \mathrm{ppm}$ & HPLC-UV & {$[36]$} \\
\hline & & & $(\lambda=290 \mathrm{~nm})$ & \\
\hline \multirow[t]{6}{*}{ Clay Loam } & 66 & 1000 ppm & ELISA & {$[35]$} \\
\hline & $156 \pm 8$ & $3 \mathrm{ppm}$ & HPLC-MS (SIM) & [6] \\
\hline & $1.76-6.19$ & $0.5,5,50 \mathrm{ppm}$ & HPLC-UV & {$[25]$} \\
\hline & & & $(\lambda=290 \mathrm{~nm})$ & \\
\hline & 65 & $5 \mathrm{ppm}$ & HPLC-UV & {$[36]$} \\
\hline & & & $(\lambda=290 \mathrm{~nm})$ & \\
\hline \multirow[t]{6}{*}{ Loam } & $59.35-1176.00$ & $10,100,200,1000 \mathrm{ppb}$ & HPLC-MS (ion trap) & ED \\
\hline & & & & Method 2 \\
\hline & $1684-172480$ & $1,5,10,100,200,500,1000 \mathrm{ppb}$ & HPLC-MS/MS & ED \\
\hline & & & & Method 3 \\
\hline & $5.77-12.4$ & $0.5,5,50 \mathrm{ppm}$ & HPLC-UV & {$[25]$} \\
\hline & & & $(\lambda=290 \mathrm{~nm})$ & \\
\hline \multirow[t]{3}{*}{ Loamy Sand } & $8.3 \pm 1.2$ & 500 ppb & LC-MS & {$[37]$} \\
\hline & & & LC-fluorescence & \\
\hline & $8.9 \pm 0.4$ & $3 \mathrm{ppm}$ & HPLC-MS (SIM) & [6] \\
\hline \multirow[t]{4}{*}{ Sand Soil } & $10.8 \pm 0.7$ & $500 \mathrm{ppb}$ & LC-MS & {$[37]$} \\
\hline & & & LC-fluorescence & \\
\hline & 24 & $5 \mathrm{ppm}$ & HPLC-UV & {$[36]$} \\
\hline & & & $(\lambda=290 \mathrm{~nm})$ & \\
\hline \multirow[t]{2}{*}{ Clay\%: $0.2-51.6 \%$} & 10.4-387.0 & $3-7.5 \mathrm{ppm}$ & HPLC-MS (SIM) & [38] \\
\hline & (Average $=129.5)$ & & & \\
\hline \multirow[t]{6}{*}{ Clay\%: < $3-69 \%\left(K_{d}\right.$ increases with clay \%) } & $2.23-5520$ & $5-43 \mu \mathrm{mol} / \mathrm{L}$ & HPLC-UV, & {$[2]$} \\
\hline & (Tylosin A) & & $(\lambda=280 \mathrm{~nm})$ & \\
\hline & $547-4745$ & $5-43 \mu \mathrm{mol} / \mathrm{L}$ & HPLC-UV, & [2] \\
\hline & (Tylosin D) & & $(\lambda=280 \mathrm{~nm})$ & \\
\hline & $597-6520$ & $5-43 \mu \mathrm{mol} / \mathrm{L}$ & HPLC-UV, & [2] \\
\hline & (Tylosin A-Aldol) & & $(\lambda=280 \mathrm{~nm})$ & \\
\hline
\end{tabular}

Note: Results are soil dependent. ED: experimentally determined. Methodology can be found in the additional files. $\mathrm{K}_{\mathrm{ow}}$ ranges for tylosin A and it's metabolites: tylosin A: 0.552-32.6587; tylosin B: 1.535-78.343; tylosin C: 0.676-41.495;tylosin D: 0.309-17.947. $\mathrm{K}_{\text {ow }}$ values calculated using Advanced Chemistry Development (ACD/Labs) Software V11.02 (๑ 1994-2012 ACD/Labs).

linear isotherm with a slope equal to $n$ and a y-intercept equal to $\log \mathrm{K}_{\mathrm{f}}$. If the value of $\mathrm{K}_{\mathrm{f}}$ approaches the value of $K_{d}$, the Freundlich exponent, $n$, is equal to 1 , and sorption is linear. If $n$ is greater than 1 , the sorption coefficient increases as the amount of compound sorbed on the solid phase increases; this indicates that the presence of sorbed compounds on the solid induces further sorption of additional compounds. If $n$ is less than 1 , sorption coefficient decreases when the amount of compound sorbed is increased; this indicates that the presence of sorbed compounds hinders further sorption [29]. 

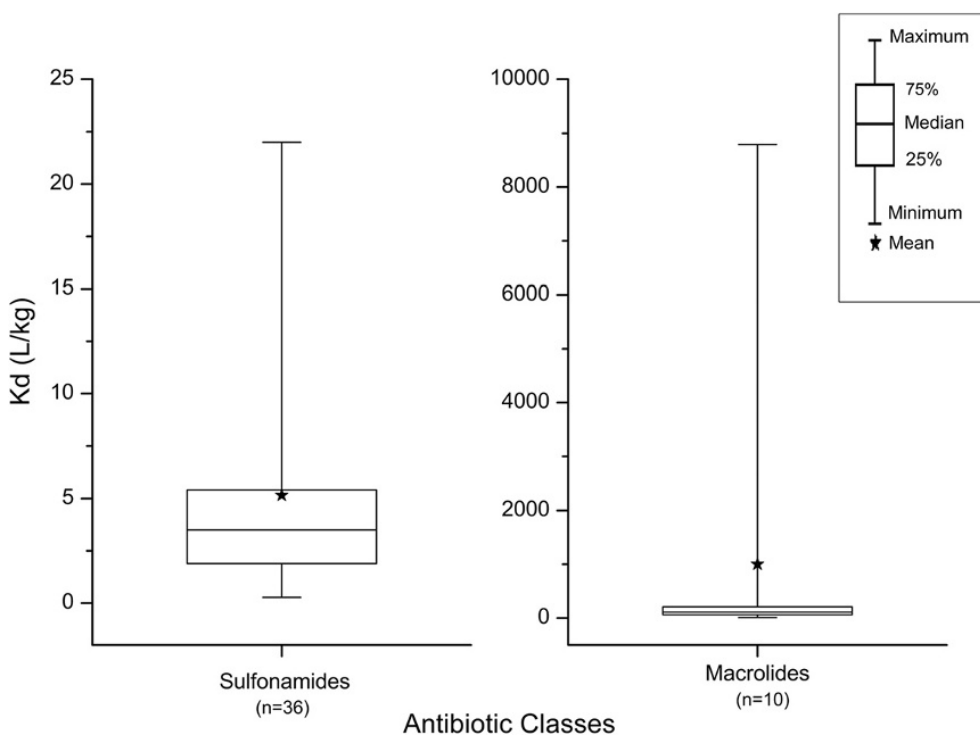

Figure 1 Box plots of $K_{d}$ values for sulfonamides and macrolides reported in literature. The sulfonamides (left) include sulfamethazine and sulfachloropyridazine, and the macrolides (right) includes tylosin and erythromycin. pH values range from 5.2-7.5 when reported. Soil types include loamy and sandy loam, clay loam, loam, loamy sand, and silt loam. The high variation of $\mathrm{K}_{\mathrm{d}}$ values found in literature is illustrated here. The upper and lower boundaries of the box represent the $75^{\text {th }}$ and $25^{\text {th }}$ percentile respectively. The middle line indicates the median value, and the whiskers indicate the maximum and minimum values.

An alternative to $\mathrm{K}_{\mathrm{d}}$ : normalizing with organic carbon, $\mathrm{K}_{\mathrm{oc}}$ Experimental determination of $K_{d}$ values can be costprohibitive and time-consuming because one has to measure $K_{d}$ at various conditions (e.g. different soil types, $\mathrm{pH}$ values, and organic and ionic strengths). When $K_{d}$ is normalized to the organic carbon content of the soil, the organic carbon normalized sorption coefficient $\mathrm{K}_{\mathrm{oc}}$ is obtained [1]:

$$
K_{o c}=\frac{K_{d}}{f_{o c}}
$$

However, mechanisms other than hydrophobic interactions are not accurately accounted for when normalization is performed using organic carbon content [1]. The differences between $\mathrm{K}_{\mathrm{oc}}$ and $\mathrm{K}_{\mathrm{d}}$ are observed in literature. Rabølle and Spliid [37] reported $\mathrm{K}_{\mathrm{d}}$ and $\mathrm{K}_{\mathrm{oc}}$ values ranging from $8.3-128 \mathrm{~L} / \mathrm{kg}$ and $553-7988 \mathrm{~L} / \mathrm{kg}$, respectively, for tylosin in 4 different soils. Lertpaitoonpan et al. [33] reported $\mathrm{K}_{\mathrm{d}}$ values for sulfamethazine for 5 different soils at varying $\mathrm{pH}$ between $0.23-3.91 \mathrm{~L} / \mathrm{kg}$, and $\mathrm{K}_{\mathrm{oc}}$ values between $30.4-139.7 \mathrm{~L} / \mathrm{kg}$. In both cases, the antibiotics have higher $K_{o c}$ values, which would suggest that the compounds are less mobile than their $K_{d}$ values would indicate. Thus, while normalizing partition coefficients may help reduce variation between samples, it cannot be universally applied to all antimicrobials, particularly those that have ionizable functional groups.

\section{Case studies: sorption behavior of sulfonamides and macrolides in sediment}

Macrolides and sulfonamides are commonly used antibiotic classes in livestock. Approximately $165800 \mathrm{~kg}$ of tylosin (a macrolide), $18660 \mathrm{~kg}$ of sulfamethazine, and $19400 \mathrm{~kg}$ of sulfathiazole are used annually in the United States for growth promotion, prevention, and therapy [42]. Our laboratory conducted sorption experiments for sulfamethazine and tylosin under varying $\mathrm{pH}$, OM content, and ionic strengths using loam and sandy loam sediments. A study by Kim et al. [43] found sulfamethazine, erythromycin-hydrochloride, and tylosin in agricultural soils at concentrations of 9.1, 30.7, and $19.6 \mu \mathrm{g} / \mathrm{kg}$, respectively. Therefore, sorption tests were performed using aqueous concentrations between 1-1000 $\mu \mathrm{g} / \mathrm{L}$ prior to partitioning in order to mimic environmentally relevant concentrations of these antibiotics. Details regarding the methodology used to perform these batch experiments can be found in Additional file 1.

The pH-dependence of antibiotic sorption is critical, because many pharmaceuticals have acid-base properties resulting in changes in the overall net charge of the molecule as ammonia concentration in manure changes [6]. These factors can alter the distribution between the aqueous and solid phase, particularly for ionizable compounds [23]. Changes in soil pH can also affect surface charge and cation exchange capacity of the soil [1]. Ionic strength variations can lead to changes in $\mathrm{pH}$, and cause electrostatic competition between ions present in the solution and the 
analyte of interest [6,44-46]. This study makes use of sediments that have similar OM content but have different fractions of sand, silt and clay. Most of the study conditions render a percentage of the compound in its ionized form, and due to the dependence on ionic strength, the antibiotics in the cationic form show increased sorption. However, sediment buffering capacity must be considered. The higher clay content in the loam sediment has a weaker buffering capacity relative to OM [47]. The sandy loam can more readily adjust the $\mathrm{pH}$ closer to the original $\mathrm{pH}$, and therefore antibiotic sorption in sandy loam is less affected by changes in $\mathrm{pH}$. The water solubility of the antibiotics increases with increase in dissolved OM content [48], which in turn results in increased mobility of antibiotics in soil [1]. Thus, it is important to understand how the $K_{d}$ changes for each antibiotic when OM is present in the system.

\section{Sulfamethazine}

Sulfonamides, or sulfa drugs, are synthetic antimicrobial agents containing the sulfonamide functional group $\left(-\mathrm{RSO}_{2} \mathrm{NH}_{2}\right)$ [10]. Sulfonamides are mobile antibiotics and their speciation changes with $\mathrm{pH}$. A common sulfonamide antibiotic is sulfamethazine $\left(\mathrm{pk}_{\mathrm{a}}: 1.62,7.91\right)$, and its $\mathrm{K}_{\mathrm{d}}$ values for various soil types reported in literature are presented in Table 1, and compared with the $K_{d}$ values obtained experimentally from our laboratory.

\section{Effects of $\mathrm{pH}$ on sulfamethazine sorption}

The sorption isotherm we determined for sulfamethazine (Figure 2) illustrates that $K_{d}$ generally decreases with increase in $\mathrm{pH}$ for both loamy sand and loam sediments. This sorption behavior is consistent with the changes in the fraction of ionization of sulfamethazine as it converts from its cationic form to the neutral and anionic forms (See Figure 3). Positively charged species are electrostatically attracted to the negatively charged soil surface, and therefore a higher $\mathrm{K}_{\mathrm{d}}$ is observed at $\mathrm{pH}$ below 5 (Table 3) [2,30]. Despite the presence of a small fraction of negatively charged sulfamethazine at $\mathrm{pH} 7$, cation bridging does not appear to play a significant role in the sorption of sulfamethazine because sulfonamides interact primarily with soil organic matter via hydrophobic interactions [49]. This behavior of sulfonamides is in contrast with tetracycline and fluoroquinolone family of antibiotics that interact with soils primarily through cation exchange, surface complexation and cation bridging sorption mechanisms.

Sulfamethazine sorption (Table 3) trends towards linear isotherms in the sandy loam $\left(\mathrm{n}_{\mathrm{pH} 5}=0.916, \mathrm{n}_{\mathrm{pH} 7}=\right.$ 0.853 , and $n_{\mathrm{pH} 9}=1.01$ ) at the three $\mathrm{pH}$ values tested. Sorption in loam exhibits some non-linearity $\left(\mathrm{n}_{\mathrm{pH} 4}=\right.$ $0.885, \mathrm{n}_{\mathrm{pH} 6.9}=0.822$, and $\left.\mathrm{n}_{\mathrm{pH} 8.2}=0.708\right)$. The $\mathrm{n}$ values are less than 1 which signifies that the sorption coefficient decreases when the amount of compound sorbed is increased, indicating that the presence of sorbed compounds hinders further sorption of antibiotic $[29,50]$.

\section{Effects of ionic strength on sulfamethazine sorption}

Sulfamethazine showed a slight decrease in sorption when ionic strength was increased from $50 \mathrm{mM}$ to 250 $\mathrm{mM}$ (Table 4). The small decrease in sulfamethazine sorption may be attributed to a slight change in $\mathrm{pH}$ brought about by increase in ionic strength, and a possible change in interfacial potential between the negative sediment surface and the partially charged sulfamethazine [44-46]. The negatively charged soil surface reduces the sorption of anionic organic compounds [6,51].

\section{Effects of organic matter on sulfamethazine sorption}

Fan et al. [31] found that the sorption correlation of sulfamethazine with $\mathrm{OM}$ is confounded by soil $\mathrm{pH}$. Thiele-Bruhn and Aust [52] observed that when electrostatic competition were eliminated through use of an acidic pig slurry matrix, the sorption of sulfonamides decreased. Decreased antibiotic sorption may be attributed to association of sediments with OM from manure components (ammonia-N-containing soluble hydrocarbons such as amino acids urea [53,54], and N-heterocyclic hydrocarbons such as pyrrols, methylindols, and nitrogen bases [55]). The interaction of OM with soil can block access of antibiotics to interlayer sorption sites in soil $[25,52,56]$. In our study, we found no consistent trend with changes in humic acid (HA) concentrations (Table 5). These tests may have been complicated by the presence of both dissolved and suspended HA in solution. Suspended HA provides sites where additional partitioning can occur. Increased amounts of dissolved OM can cause antibiotics to desorb from soil, and increased association of antibiotics with dissolved OM can facilitate transport in the environment [1,16,57]. Furthermore, any anionic sulfamethazine may be repelled by the increased surface charge occurring from the dissolved OM [30].

\section{Tylosin}

Macrolides, which are mainly active to Gram-positive bacteria, inhibit ribosomal protein synthesis. Their activity stems from the presence of the macrolide ring, a large lactone ring to which one or more deoxy sugars are attached [58]. A case study on the soil sorption of tylosin antibiotic, which belongs to the macrolide class, is presented below.

\section{Effects of $\mathrm{pH}$ on tylosin sorption}

Tylosin sorption $\left(\mathrm{pK}_{\mathrm{a}}\right.$ : 7.20, 12.44, 12.93, 13.36, 13.94, and 15.01; assignments of pKa values in the molecule are shown in Scheme 1) strongly depends on the $\mathrm{pH}$, as well as on the surface area, clay content, and cation- 

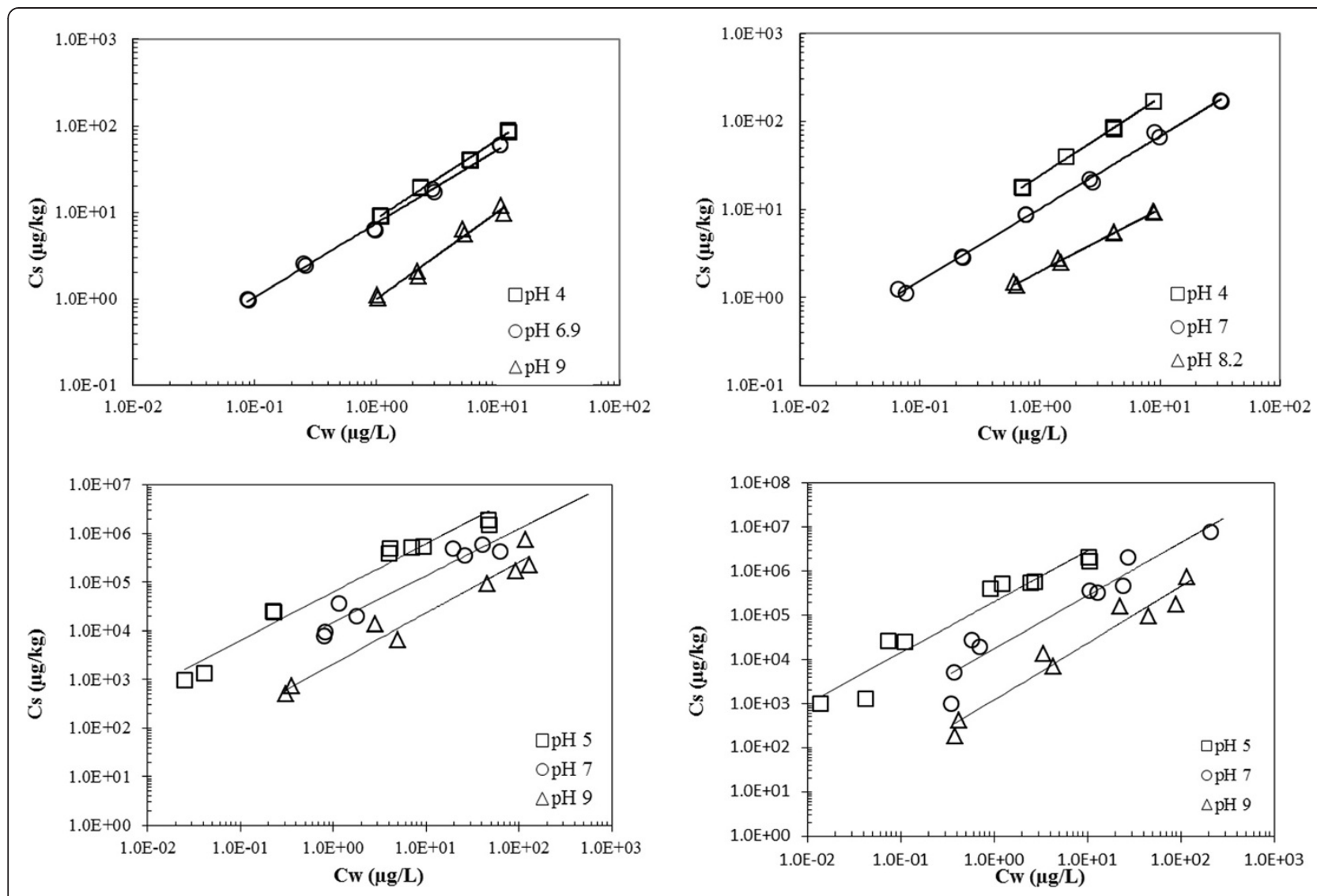

Figure 2 Sulfamethazine sorption isotherms. Top: Sulfamethazine sorption isotherms in sediment at low, neutral, and high aqueous pH. Left: sandy-loam and Right: loam Bottom: Tylosin sorption isotherms in sediment at low, neutral, and high aqueous pH. Left: sandy-loam and Right: loam

exchange capacity of the soil [2]. Since tylosin is water soluble $(5 \mathrm{mg} / \mathrm{mL})$ and has high molecular weight, it is unlikely that sorption occurs through penetration of soil micro pores [25]. Several studies have reported that the $K_{d}$ values for tylosin increase with decreasing $\mathrm{pH}$ $[6,25,38,59]$. The same $\mathrm{pH}$ effects on the sorption behavior of tylosin were observed in the studies conducted in our laboratory, as shown in Figure 2 and in Table 3. Tylosin sorption increased in both loam and sandy loam sediments when the $\mathrm{pH}$ of the sediment-aqueous system was decreased. The increased sorption of tylosin at $\mathrm{pH} 5$, relative to its sorption at $\mathrm{pH} 7$ and 9 can be expected due to the shift in tylosin speciation towards the positively charged species, resulting in increased

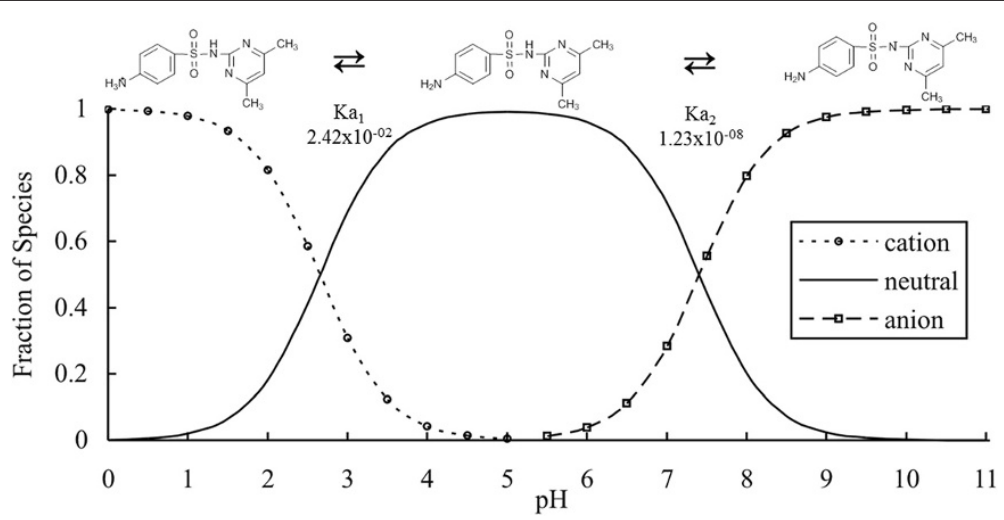

Figure 3 Distribution of sulfamethazine species by $\mathrm{pH}$. Sulfamethazine is predominantly cationic below pH 1.62, neutral between pH $1.62-7.91$, and anionic above pH 7.91. The chemical structures that represent the highest fraction of species is shown above the curve. 
Table 3 Sulfamethazine and tylosin partitioning with changes in $\mathrm{pH}$

\begin{tabular}{|c|c|c|c|c|c|c|c|c|c|}
\hline \multirow[b]{2}{*}{ Antibiotic } & \multirow[b]{2}{*}{$\mathrm{pH}$} & \multicolumn{4}{|c|}{ Sandy loam } & \multicolumn{4}{|c|}{ Loam } \\
\hline & & $\mathrm{K}_{\mathrm{d}}(\mathrm{L} / \mathrm{kg})$ & $\mathrm{R}^{2}$ & $K_{f}$ & $\mathrm{R}^{2}$ & $\mathrm{~K}_{\mathrm{d}}(\mathrm{L} / \mathrm{kg})$ & $\mathrm{R}^{2}$ & $K_{f}$ & $\mathrm{R}^{2}$ \\
\hline \multirow[t]{3}{*}{ Sulfamethazine } & 5 & $6.9 \pm 0.5$ & 0.996 & 8.49 & 0.997 & $18 \pm 1$ & 0.998 & 24.3 & 0.999 \\
\hline & 7 & $5.1 \pm 0.3$ & 0.997 & 7.54 & 0.996 & $5.3 \pm 0.7$ & 0.985 & 10.3 & 0.998 \\
\hline & 9 & $0.9 \pm 0.3$ & 0.954 & 0.994 & 0.980 & $0.9 \pm 0.1$ & 0.990 & 1.98 & 0.995 \\
\hline \multirow[t]{3}{*}{ Tylosin } & 5 & $3 \times 10^{4} \pm 1 \times 10^{4}$ & 0.933 & $6.28 \times 10^{4}$ & 0.967 & $1.7 \times 10^{5} \pm 4 \times 10^{4}$ & 0.952 & $2.02 \times 10^{5}$ & 0.933 \\
\hline & 7 & $1.5 \times 10^{4} \pm 6 \times 10^{3}$ & 0.899 & $1.43 \times 10^{4}$ & 0.950 & $2.2 \times 10^{4} \pm 7 \times 10^{3}$ & 0.933 & $1.66 \times 10^{4}$ & 0.867 \\
\hline & 9 & $7 \times 10^{3} \pm 3 \times 10^{3}$ & 0.872 & $2.21 \times 10^{3}$ & 0.962 & $1.7 \times 10^{3} \pm 9 \times 10^{2}$ & 0.808 & $1.26 \times 10^{3}$ & 0.938 \\
\hline
\end{tabular}

Note: Values were experimentally determined. Errors represent standard deviation. Methodology can be found in the additional files. Sulfamethazine data was performed using method 1 and tylosin data with method 2 . Sulfamethazine batch experiments were performed with concentrations of $1,3,5,10,20,30,50,100$, and $300 \mathrm{ng} / \mathrm{mL}$, and tylosin batch experiments were performed with concentrations of 1, 5, 10, 100, 200, 500, and $\mathrm{ng} / \mathrm{mL}$.

electrostatic attractions to the negatively charged sediment surface [25].

Our experimental values indicate that tylosin sorption (Table 3 ) is linear over 3 orders of magnitude in the sandy loam sediment at $\mathrm{pH} 5$ and $7\left(\mathrm{n}_{\mathrm{pH} 5}=0.993, \mathrm{n}_{\mathrm{pH} 7}=1.05\right)$. However, at $\mathrm{pH} 9, \mathrm{n}_{\mathrm{pH}}=1.22$; this greater than unity value indicates a non-linear sorption behavior that can be attributed to the presence of sorbate molecules inducing further sorption [29]. In other words, the presence of the sorbed tylosin results in further sorption of the antibiotic in soil. Similarly, the loam sediment exhibits some nonlinearity $\left(\mathrm{n}_{\mathrm{pH} 5}=1.15, \mathrm{n}_{\mathrm{pH} 7}=1.18, \mathrm{n}_{\mathrm{pH} 9}=1.19\right)$, but to a lower extent. Thus, electrostatic forces dominate the sorption model.

\section{Effects of ionic strength on tylosin sorption}

Literature suggests that tylosin sorption decreases with increase in ionic strength due to the consequent change in $\mathrm{pH}$, and as a result of competition between the electrolyte cations and the positively charged tylosin species for negatively charged sorbent [6]. However, ionic strength experiments performed in our laboratory at a constant $\mathrm{pH}$ of 7 , with tylosin in mostly neutral form, showed a reverse trend (Table 4). Instead, at $\mathrm{pH} \mathrm{7,} \mathrm{tylosin} \mathrm{sorption} \mathrm{in-}$ creased with increase in ionic strength. This sorption behavior may be attributed to the presence of hydrated cations in the solution $\left(\mathrm{Ca}^{2+}, \mathrm{Na}^{+}\right)$that may act as protondonors, which can protonate the tertiary amine in the tylosin molecule and enhance its sorption properties at higher ionic strengths. Yong-Hak et al. [60], observed that the tertiary amine group of erythromycin can become protonated, and that clay surfaces can facilitate this with their proton supplying power. Alternatively, hydrated cations that adsorb on the negatively charged soil can provide hydrogen bonding as an important sorption mechanism for tylosin because of several $\mathrm{OH}$ groups present in the molecule.

\section{Effect of organic matter on tylosin sorption}

It was expected that the $K_{d}$ values for tylosin would decrease in the presence of OM due to increased solubility. However, studies in our laboratory demonstrated higher $\mathrm{K}_{\mathrm{d}}$ values with increased OM (represented as humic acids) using $10 \mathrm{ppm}$ tylosin in sandy loam, and unchanged values in loam (Table 5). Similar to sulfamethazine, complications could arise from the presence of both dissolved and suspended OM within the solution. This complexity can be observed in the change in $K_{f}$ values with increasing tylosin concentration (Table 5). Likewise, differences in the sorbates can also influence sorption, as was observed in the sorption of tylosin to the two sediment types used in our laboratory study.

Table 4 Sulfamethazine and tylosin partitioning with changes in ionic strength

\begin{tabular}{|c|c|c|c|c|c|c|c|c|c|}
\hline \multirow[b]{2}{*}{ Antibiotic } & \multirow[b]{2}{*}{ lonic strength (mM) } & \multicolumn{4}{|c|}{ Sandy loam } & \multicolumn{4}{|c|}{ Loam } \\
\hline & & $K_{d}(L / k g)$ & $\mathrm{R}^{2}$ & $K_{f}$ & $\mathrm{R}^{2}$ & $K_{d}(L / k g)$ & $\mathrm{R}^{2}$ & $K_{f}$ & $\mathrm{R}^{2}$ \\
\hline \multirow[t]{3}{*}{ Sulfamethazine } & 30 & $10.3 \pm 0.5$ & 0.999 & 26 & 0.992 & $5.5 \pm 0.8$ & 0.991 & 46 & 0.978 \\
\hline & 50 & $10 \pm 1$ & 0.994 & 47 & 0.991 & $7.5 \pm 0.5$ & 0.997 & 59 & 0.960 \\
\hline & 250 & $7 \pm 3$ & 0.913 & 54 & 0.974 & $2.8 \pm 0.3$ & 0.995 & 84 & 0.917 \\
\hline \multirow[t]{3}{*}{ Tylosin } & 30 & $500 \pm 45$ & 0.969 & 1640 & 0.969 & $190 \pm 30$ & 0.984 & 2689 & 0.919 \\
\hline & 50 & $2.9 \times 10^{3} \pm 1 \times 10^{2}$ & 0.999 & 4411 & 0.980 & $600 \pm 300$ & 0.886 & 3109 & 0.972 \\
\hline & 250 & $1.4 \times 10^{4} \pm 7 \times 10^{3}$ & 0.927 & 17200 & 0.935 & $9.6 \times 10^{3} \pm 7 \times 10^{2}$ & 0.998 & 5555 & 0.937 \\
\hline
\end{tabular}

Note: Values were experimentally determined. Errors represent standard deviation. Methodology can be found in the additional files. Sulfamethazine data was performed using method 1 and tylosin data with method 2. Sulfamethazine batch experiments were performed with concentrations of $17.7,35.4,53.1,70.8,88.5$ $\mathrm{ng} / \mathrm{mL}$, and tylosin batch experiments were performed with concentrations of $10,100,500$, and $1000 \mathrm{ng} / \mathrm{mL}$. 
Table 5 Sulfamethazine and tylosin partitioning with changes in organic strength

\begin{tabular}{|c|c|c|c|c|c|c|c|c|c|}
\hline \multirow[b]{2}{*}{ Antibiotic } & \multirow[b]{2}{*}{$\begin{array}{c}\text { Humic acid } \\
(\mathrm{mg} / \mathrm{L})\end{array}$} & \multicolumn{4}{|c|}{ Sandy loam } & \multicolumn{4}{|c|}{ Loam } \\
\hline & & $\begin{array}{c}\mathrm{K}_{\mathrm{d}} \\
(\mathrm{L} / \mathrm{kg})\end{array}$ & $\mathrm{R}^{2}$ & $\mathrm{~K}_{\mathrm{f}}$ & $\mathrm{R}^{2}$ & $\begin{array}{c}K_{d} \\
(L / k g)\end{array}$ & $\mathrm{R}^{2}$ & $K_{f}$ & $\overline{R^{2}}$ \\
\hline \multirow[t]{3}{*}{ Sulfamethazine } & 1 & $9 \pm 2$ & 0.974 & 31 & 0.910 & $5 \pm 2$ & 0.918 & 70 & 0.913 \\
\hline & 10 & $3 \pm 2$ & 0.727 & 67 & 0.947 & $4 \pm 2$ & 0.878 & 84 & 0.827 \\
\hline & 50 & $12 \pm 3$ & 0.960 & 50 & 0.910 & $6 \pm 2$ & 0.961 & 86 & 0.958 \\
\hline \multirow[t]{3}{*}{ Tylosin } & 1 & $60 \pm 30$ & 0.869 & $1.43 \times 10^{5}$ & 0.873 & $50 \pm 10$ & 0.960 & $1.66 \times 10^{5}$ & 0.983 \\
\hline & 10 & $90 \pm 20$ & 0.976 & $4.41 \times 10^{3}$ & 0.940 & $50 \pm 50$ & 0.715 & $1.77 \times 10^{4}$ & 0.829 \\
\hline & 50 & $140 \pm 70$ & 0.936 & $8.18 \times 10^{4}$ & 0.996 & $40 \pm 30$ & 0.714 & $1.19 \times 10^{5}$ & 0.975 \\
\hline
\end{tabular}

Note: Values were experimentally determined. Errors represent standard deviation. Methodology can be found in the additional files. Sulfamethazine data was performed using method 1 and tylosin data with method 2. Sulfamethazine batch experiments were performed with concentrations of $17.7,35.4,53.1,70.8,88.5$ $\mathrm{ng} / \mathrm{mL}$, and tylosin batch experiments were performed with concentrations of $10,15,30$, and $50 \mathrm{mg} / \mathrm{L}$.

\section{Sorption of tylosin metabolites}

Tylosin and other antibiotics may interconvert between multiple chemical forms depending on environmental conditions as shown in Figure 4. Tylosin A and its related compounds are stable from $\mathrm{pH}$ 4-9 [61]. Metabolism of tylosin by livestock results in the excretion of tylosin A, B, $\mathrm{D}$, and dihydrodesmycosin metabolites $[2,62,63]$. As the metabolites retain different degrees of bioactivity $(\mathrm{TA}=100 \%$, relative, $\mathrm{TB}=83 \%, \quad \mathrm{TD}=35 \%$, dihydrodesmycosin $=31 \%$ ) [2], it is important to consider the speciation of tylosin present in the environment. Tylosin A, D, and tylosin A-Aldol have been found to exhibit similar sorption characteristics [2]. However differences in sorption behavior between tylosin A ( $\mathrm{K}_{\mathrm{ow}}$ : 0.552-32.659) and its hydrolysis

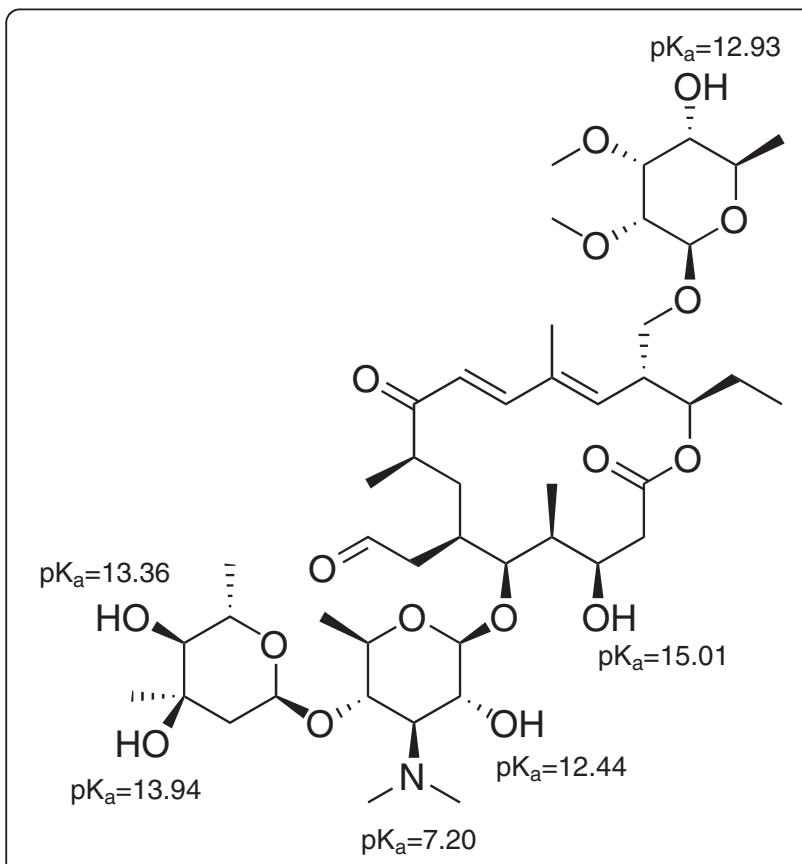

Scheme 1 The macrolide, tylosin. Chemical structure and $\mathrm{pK}_{\mathrm{a}}$ values are shown. product tylosin B (spiramyycin, $\mathrm{K}_{\mathrm{ow}}$ : $1.535-78.343$ ) may be significant. Tylosin B results from the hydrolysis of tylosin A which involves a loss of the mycarose ring attached at position 4 of the 16-membered lactone ring. With this loss, the hydrophilicity of tylosin increases. This can alter tylosin's potential to sorb to soil through hydrophobic interactions, and tylosin B can potentially be more mobile in the environment. Therefore, due to the varying properties of the different forms of tylosin, including tylosin A, B, C, and $D$ it may not be appropriate to use only one $K_{d}$ value for risk assessment of tylosin. Rather, $K_{d}$ values should be obtained for all forms possible under the expected conditions.

To date, studies on the environmental fate of tylosin A degradation products are very limited $[2,24]$. Our laboratory determined sorption differences between tylosin A and $\mathrm{B}$ in loam sediment at an initial concentration of $50 \mu \mathrm{g} / \mathrm{mL}$ equilibrated between sediment and aqueous phase for $24 \mathrm{~h}$. The amount of tylosin remaining in the aqueous phase was determined by liquid chromatography coupled to an ion trap mass spectrometer (LC-MS) following concentration by solid phase extraction (SPE). The methodology used follows that in method 2 of the additional file 1 . It was found that $53 \%$ tylosin $\mathrm{A}$ and $39 \%$ tylosin B were sorbed in the loam. However, these results may be complicated by the hydrolysis of tylosin over the equilibration time period and during the SPE process. A study by Ali et al. [64] observed a decrease in sorption with decreasing $\mathrm{pH}$. This result is contradictory to what is found in most of the studies reported in the literature. The decrease may be associated with the decrease in tylosin A due to the formation of tylosin metabolites. The conversion of the parent compound to metabolites and the interconversions that occur under varying conditions are challenges associated with analyzing degradation products.

\section{Conclusions}

It is not possible to determine the fate and mobility of antibiotics and antimicrobials in the environment with 


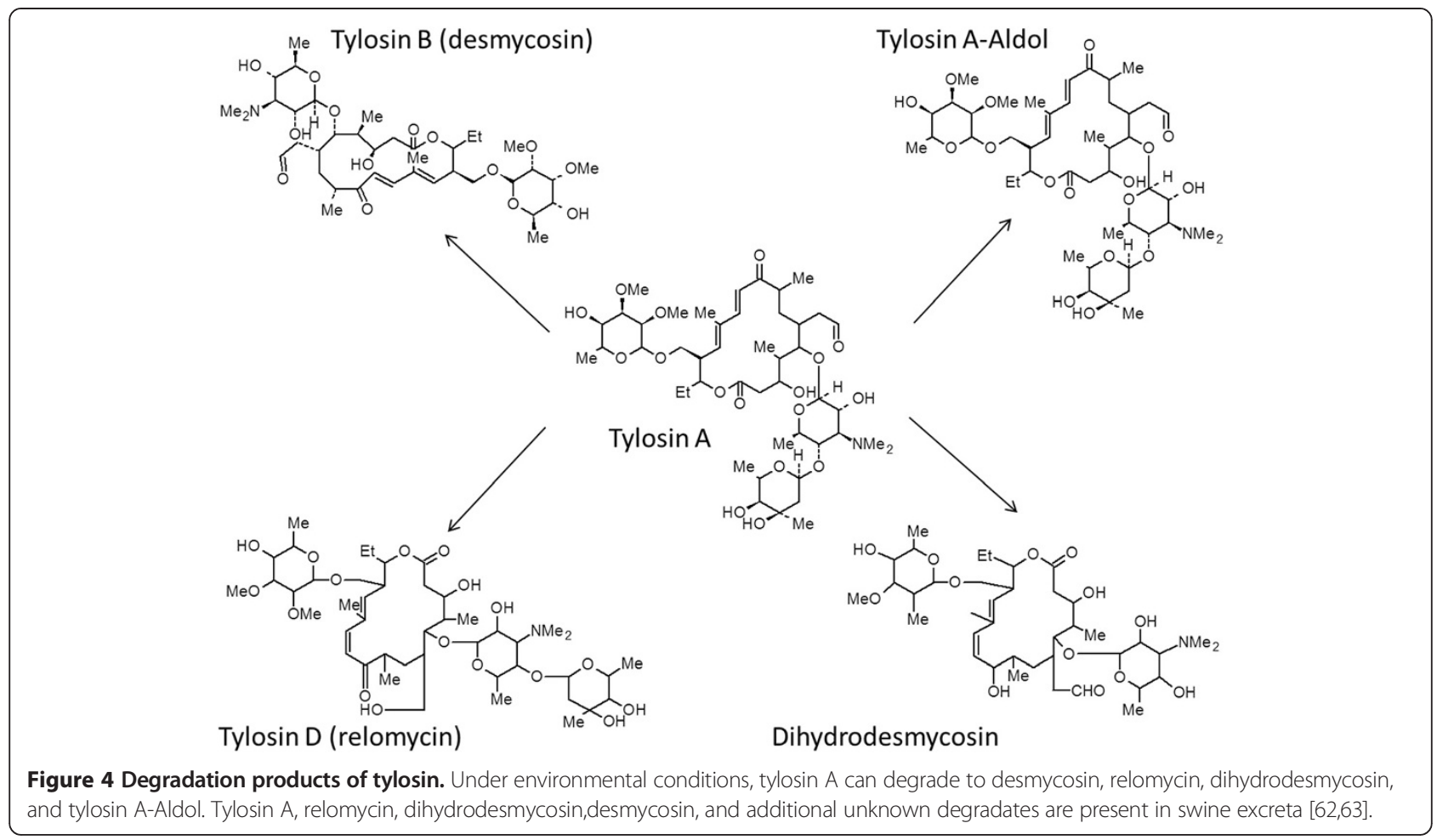

$\mathrm{K}_{\mathrm{ow}}$ values alone. The variability in mobility, as demonstrated by $K_{d}$ and $K_{f}$ values due to environmental factors such as $\mathrm{pH}$, ionic strength, and organic strength as well as the multiple chemical functions of the molecule are large. In the case studies presented here, sulfamethazine was found to be very mobile in sandy loam and loam sediments, while tylosin is very immobile in both sediments. It is possible that degradates may have a higher mobility than the parent compounds. It is also important to determine sorption coefficients of antibiotics at environmentally-relevant concentrations. To achieve this, highly sensitive analytical techniques must be used, including the use of radiolabeled compounds.

A decrease in solution $\mathrm{pH}$ resulted in an increase in sorption of the cationic forms of antibiotics suggesting that electrostatic forces are the favored sorption mechanism of sulfamethazine and tylosin. As with other known pharmaceuticals, ionization of these compounds at the conditions considered was shown to favor the sorption of compounds. A cation-exchange mechanism can also be envisioned based on the results of ionic strength experiments where ions compete with charged species for sites on the soil. Organic matter dependence of $\mathrm{K}_{\mathrm{d}}$ appears to be concentration-dependent, where low antibiotic concentrations result in higher soil sorption, and higher antibiotic concentrations result in lower soil sorption. It is observed that sorption mechanisms are much more complex than simple hydrophobicity and hydrogen bonding, and should also consider van der
Waals and electrostatic interactions, as well as cationexchange, competition and bridging. Additionally, the properties of the sorbent also affect the sorption process. Differences in clay content alone provide notable changes in $K_{d}$ values. Finally, sorption of antibiotics in soil, manure, and biosolids can be microbially-mediated, and may result in degradation or possibly irreversible binding onto manure solids with time $[25,40,62,65]$. Fate and transport studies should take into account not only $K_{d}$ values for the parent compounds, but also those of the transformation products formed during biotic and abiotic processes in soil.

\section{Additional file}

Additional file 1: Methodology for Sorption Batch Experiments.

\section{Abbreviations}

VPs: Veterinary pharmaceuticals; $\mathrm{K}_{\text {ow: }}$ Octanol-water partition coefficient; $D_{\text {ow: }}$ : $\mathrm{PH}$ dependent octanol-water distribution ratio; $\mathrm{K}_{\mathrm{d}}$ : Soil-water partition coefficient; $C_{s}$ : Concentration of compound in soil; $C_{w}$ : Concentration of dissolved compound in water; PAH: Poly aromatic hydrocarbon; Koc: Organic carbon normalized sorption coefficient; OM: Organic matter; DOM: Dissolved organic matter; HA: Humic acid; TA: Tylosin A; TB: Tylosin B; TD: Tylosin D; LC-MS/MS: Liquid chromatography tandem mass spectrometry; SPE: Solid phase extraction.

\section{Competing interests}

The authors declare that they have no competing interests. 


\section{Authors' contributions}

SRW, DAGN, and LZ performed experiments and analyzed data. SRW drafted the manuscript. DSA devised the study, secured funding, and supervised personnel during sampling, analysis and manuscript preparation. All authors read and approved the final manuscript.

\section{Acknowledgements}

Original research was supported by the United States Department of Agriculture (USDA) Award no. 2006-35102-17206, sun-contracted through the University of lowa. The authors acknowledge Dr. Joseph Bidwell from Oklahoma State University, Stillwater, OK, and Dr. Joel Coats and Keri Henderson from lowa State University, Ames, IA for kindly providing the pond sediments used in the experiments. Stacia Wegst-Uhrich acknowledges her IGERT fellowship support from the National Science Foundation (NSF), Grant No. DGE-0654305, titled "Ecosystem Restoration through Interdisciplinary Exchange" Traineeship Program.

\section{Author details}

'Department of Chemistry, University at Buffalo, State University of New York, Buffalo, NY 14260, USA. ${ }^{2}$ Commonwealth Scientific and Industrial Research Organization, Private Bag 2, Glen Osmond, SA 5064, Australia.

Received: 15 August 2013 Accepted: 14 January 2014

Published: 17 January 2014

\section{References}

1. Tolls J: Sorption of veterinary pharmaceuticals in soils: a review. Environ Sci Tech 2001, 35:3397-3406.

2. Sassman SA, Sarmah AK, Lee LS: Sorption of tylosin A, D, and A-aldol and degradation of tylosin a in soils. Environ Toxicol Chem 2007, 26:1629-1635.

3. Pruden A, Pei R, Storteboom H, Carlson KH: Antibiotic resistance genes as emerging contaminants: studies in northern Colorado. Environ Sci Tech 2006, 40:7445-7450.

4. Pei R, Kim S-C, Carlson KH, Pruden A: Effect of river landscape on the sediment concentrations of antibiotics and corresponding antibiotic resistance genes (ARG). Water Res 2006, 40:2427-2435.

5. Kotzerke A, Sharma S, Schauss K, Heuer H, Thiele-Bruhn S, Smalla K, Wilke B-M, Schloter M: Alterations in soil microbial activity and N-transformation processes due to sulfadiazine loads in pig-manure. Environ Pollut 2008, 153:315-322

6. ter Laak TL, Gebbink WA, Tolls J: The effect of $\mathrm{pH}$ and ionic strength on the sorption of sulfachloropyridazine, tylosin, and oxytetracycline to soil. Environ Toxicol Chem 2006, 25:904-911.

7. Boxall ABA, Kolpin DW, Halling-Sørensen B, Tolls J: Are veterinary medicines causing environmental risks? Environ Sci Tech 2003, 37:286A-294A.

8. Gaskins HR, Collier CT, Anderson DB: Antibiotics as growth promotants: mode of action. Anim Biotechnol 2002, 13:29-42.

9. Elmund GK, Morrison SM, Grant DW, Nevins MP: Role of excreted chlortetracycline in modifying the decomposition process in feedlot waste. Bull Environ Contam Toxicol 1971, 6:129-132.

10. Kolpin DW, Furlong ET, Meyer MT, Thurman EM, Zaugg SD, Barber LB, Buxton HT: Pharmaceuticals, hormones, and other organic wastewater contaminants in U.S. streams, 1999-2000: a national reconnaissance. Environ Sci Tech 2002, 36:1202-1211.

11. Thiele-Bruhn S: Pharmaceutical antibiotic compounds in soils - a review. J Plant Nutr Soil Sci 2003, 166:145-167.

12. Halling-Sørensen B: Inhibition of aerobic growth and nitrification of bacteria in sewage sludge by antibacterial agents. Arch Environ Contam Toxicol 2001, 40:451-460.

13. Klaver AL, Matthews RA: Effects of oxytetracycline on nitrification in a model aquatic system. Aquaculture 1994, 123:237-247.

14. Stone JJ, Dreis EK, Lupo CD, Clay SA: Land application of tylosin and chlortetracycline swine manure: impacts to soil nutrients and soil microbial community structure. J Environ Sci Health, Part B 2011, 46:752-762.

15. Alder AC, McArdell CS, Golet EM, Ibric S, Molnar E, Nipales NS, Giger W: Occurrence and fate of fluoroquinolone, macrolide, and sulfonamide antibiotics during wastewater treatment and in ambient waters in Switzerland. ACS Symp Ser 2001, 791:56-69.

16. Kulshrestha P, Giese RF, Aga DS: Investigating the molecular interactions of oxytetracycline in clay and organic matter: insights on factors affecting its mobility in soil. Environ Sci Tech 2004, 38:4097-4105.
17. Bryskier A: Antimicrobial agents: antibacterials and antifungals. Washington D.C: ASM Press; 2005

18. Lindsey ME, Meyer M, Thurman EM: Analysis of trace levels of sulfonamide and tetracycline antimicrobials in groundwater and surface water using solid-phase extraction and liquid chromatography/mass spectrometry. Anal Chem 2001, 73:4640-4646

19. Boxall ABA, Blackwell P, Cavallo R, Kay P, Tolls J: The sorption and transport of a sulphonamide antibiotic in soil systems. Toxicol Lett 2002, 131:19-28.

20. Hirsch R, Ternes T, Haberer K, Kratz K-L: Occurrence of antibiotics in the aquatic environment. Sci Total Environ 1999, 225:109-118.

21. Boxall ABA, Johnson P, Smith E, Sinclair CJ, Stutt E, Levy LS: Uptake of veterinary medicines from soils into plants. J Agric Food Chem 2006, 54:2288-2297.

22. Hatzinger PB, Alexander M: Biodegradation of organic compounds sequestered in organic solids or in nanopores within silica particles. Environ Toxicol Chem 1997, 16:2215-2221.

23. OECD Guideline for the testing of chemicals: adsorption - desorption using a batch equilibrium method. [http://www.epa.gov/scipoly/sap/ meetings/2008/october/106_adsorption_desorption_using.pdf].

24. Hu D, Coats JR: Aerobic degradation and photolysis of tylosin in water and soil. Environ Toxicol Chem 2007, 26:884-889.

25. Zhang Q, Yang C, Dang Z, Huang W: Sorption of tylosin on agricultural soils. Soil Sci 2011, 176:407-412. 410.1097/SS.1090b1013e3182247420.

26. Wells MJM: Log DOW: key to understanding and regulating wastewater-derived contaminants. Environ Chem 2006, 3:439-449.

27. Comer JEA: High-throughput measurement of $\log D$ and $\mathrm{pK}_{\mathrm{a}}$. In Drug bioavailability: estimation of solubility, permeability, absorption and bioavailability (Methods and principles in medicinal chemistry). Volume 18. 1st edition. Edited by Waterbeemd H, Lennernäs H, Artursson P. Germany: Wiley-VCH; 2003:21-45 [Mannhold R, Kubinyi H, Folkers G (Series Editor): Methods and Principles in Medicinal Chemistry].

28. Jafvert CT, Westall JC, Grieder E, Schwarzenbach RP: Distribution of hydrophobic ionogenic organic compounds between octanol and water: organic acids. Environ Sci Tech 1990, 24:1795-1803.

29. Schwarzenbach RP, Gschwend PM, Imboden DM: Environmental organic chemistry. New York: John Wiley and Sons, Inc.; 2003.

30. Chu B, Goyne KW, Anderson SH, Lin C-H, Lerch RN: Sulfamethazine sorption to soil: vegetative management, $\mathrm{pH}$, and dissolved organic matter effects. J Environ Qual 2013, 42:794-805.

31. Fan Z, Casey FM, Hakk H, Larsen G, Khan E: Sorption, fate, and mobility of sulfonamides in soils. Water Air Soil Poll 2011, 218:49-61.

32. Kurwadkar ST, Adams CD, Meyer MT, Kolpin DW: Effects of sorbate speciation on sorption of selected sulfonamides in three loamy soils. J Agric Food Chem 2007, 55:1370-1376.

33. Lertpaitoonpan W, Ong SK, Moorman TB: Effect of organic carbon and pH on soil sorption of sulfamethazine. Chemosphere 2009, 76:558-564.

34. Srinivasan P, Sarmah AK, Manley-Harris M, Wilkins AL: Sorption of sulfamethoxazole, sulfachloropyridazine and sulfamethazine onto six New Zealand dairy farm soils. In 19th World congress of soil science, soil solutions for a changing world; August 1-6. Brisbane, Australia; 2010.

35. Gupta S, Singh A, Kumar K, Thompson A, Thoma D: Report for 200IMN1041G: Antibiotic losses in runoff and drainage from manure-applied fields. [http:// water.usgs.gov/wrri/01grants/prog-compl-reports/2001MN1041G.pdf].

36. Hu D, Coats JR: Laboratory evaluation of mobility and sorption for the veterinary antibiotic, tylosin, in agricultural soils. J Environ Monit 2009, 11:1634-1638

37. Rabolle M, Spliid NH: Sorption and mobility of metronidazole, olaquindox, oxytetracycline and tylosin in soil. Chemosphere 2000, 40:715-722.

38. ter Laak TL, Gebbink WA, Tolls J: Estimation of soil sorption coefficients of veterinary pharmaceuticals from soil properties. Environ Toxicol Chem 2006, 25:933-941.

39. van Loon GW, Duffy SJ: Environmental chemistry: a global perspective. 3rd edition. UK: Oxford University Press; 2010.

40. Kolz AC, Ong SK, Moorman TB: Sorption of tylosin onto swine manure. Chemosphere 2005, 60:284-289.

41. Bhandari A, Surampalli RY, Adams CD, Champagne P, Ong SK, Tyagi RD, Zhang TC (Eds): Contaminants of emerging environmental concern. United States of America: The American Society of Civil Engineers; 2009.

42. Apley MD, Bush EJ, Morrison RB, Singer RS, Snelson H: Use estimates of in-feed antimicrobials in swine production in the United States. Foodborne Pathog Dis 2012, 9:272-279. 
43. Kim S-C, Chung DY, Kim KH, Lee JH, Kim HK, Yang JE, OK YS, Almarwei YAO: Concentration and environmental loading of veterinary antibiotics in agricultural irrigation ditches. Korean J Soil Sci Fert 2012, 45:867-876.

44. Figueroa RA, Leonard A, Mackay AA: Modeling tetracycline antibiotic sorption to clays. Environ Sci Tech 2003, 38:476-483.

45. Sithole BB, Guy RD: Models for tetracycline in aquatic environments. Water Air Soil Pollut 1987, 32:303-314.

46. Sposito G: The chemistry of soils. 2nd edition. New York, N.Y.: Oxford University Press; 2008.

47. Rengel Z (Ed): Handbook of soil acidity. New York: Marcel Dekker, Inc.; 2003

48. Chiou C: Partition and adsorption of organic contaminants in environmental systems. Hoboken, New Jersey: John Wiley and Sons, Inc.; 2002.

49. Figueroa-Diva RA, Vasudevan D, Mackay AA: Trends in soil sorption within common antimicrobial families. Chemosphere 2010, 79:786-793.

50. Vittoria Pinna M, Castaldi P, Deiana P, Pusino A, Garau G: Sorption behavior of sulfamethazine on unamended and manure-amended soils and short-term impact on soil microbial community. Ecotox Environ Safe 2012, 84:234-242.

51. Westall JC, Chen H, Zhang W, Brownawell BJ: Sorption of linear alkylbenzenesulfonates on sediment materials. Environ Sci Tech 1999, 33:3110-3118.

52. Thiele-Bruhn S, Aust MO: Effects of pig slurry on the sorption of sulfonamide antibiotics in soil. Arch Environ Contam Toxicol 2004, 47:31-39.

53. Xing B, Pignatello JJ: Competitive sorption between 1,3-dichlorobenzene or 2,4-dichlorophenol and natural aromatic acids in soil organic matter. Environ Sci Tech 1998, 32:614-619.

54. Liang BC, Gregorich EG, Schnitzer M, Schulten H-R: Characterization of water extracts of two manures and their adsorption on soils. Soil Sci Soc Am J 1996, 60:1758-1763.

55. Kaiser K, Zech W: Soil dissolved organic matter sorption as influenced by organic and sesquioxide coatings and sorbed sulfate. Soil Sci Soc Am 1998, 62:129-136.

56. Pils JRV, Laird DA: Sorption of tetracycline and chlortetracycline on K- and Ca-saturated soil clays, humic substances, and clay - humic complexes. Environ Sci Tech 2007, 41:1928-1933.

57. Magee BR, Lion LW, Lemley AT: Transport of dissolved organic macromolecules and their effect on the transport of phenanthrene in porous media. Environ Sci Tech 1991, 25:323-331.

58. Shryock TR, Mortensen JE, Baumholtz M: The effects of macrolides on the expression of bacterial virulence mechanisms. J Antimicrob Chemother 1998, 41:505-512.

59. Gao J, Pedersen JA: Adsorption of sulfonamide antimicrobial agents to clay minerals. Environ Sci Tech 2005, 39:9509-9516.

60. Kim Y-H, Heinze TM, Kim S-J, Cerniglia CE: Adsorption and clay-catalyzed degradation of erythromycin A on homoionic clays. J Environ Qual 2004, 33:257-264.

61. O'Neil MJ: The Merck Index: an encyclopedia of chemicals, drugs, and biologicals. 12th edition. New Jersey: Merck \& Co., Inc.; 1996.

62. Kolz ACM, Moorman TB, Ong SK, Scoggin KD, Douglass EA: Degradation and metabolite production of tylosin in anaerobic and aerobic swine-manure lagoons. Water Environ Res 2005, 77:8.

63. Scott Teeter J, Meyerhoff RD: Aerobic degradation of tylosin in cattle, chicken, and swine excreta. Environ Res 2003, 93:45-51.

64. Ali M, Wang JJ, DeLaune RD, Seo DC, Dodla SK, Hernandez AB: Effect of redox potential and $\mathrm{pH}$ status on degradation and adsorption behavior of tylosin in dairy lagoon sediment suspension. Chemosphere 2013, 91:1583-1589.

65. Loke M-L, Ingerslev F, Halling-Sørensen B, Tjørnelund J: Stability of tylosin A in manure containing test systems determined by high performance liquid chromatography. Chemosphere 2000, 40:759-765.

doi:10.1186/1752-153X-8-5

Cite this article as: Wegst-Uhrich et al:: Assessing antibiotic sorption in soil: a literature review and new case studies on sulfonamides and macrolides. Chemistry Central Journal 2014 8:5.

Publish with ChemistryCentral and every
scientist can read your work free of charge
"Open access provides opportunities to our
colleagues in other parts of the globe, by allowing
anyone to view the content free of charge."
W. Jeffery Hurst, The Hershey Company.
- available free of charge to the entire scientific community
- peer reviewed and published immediately upon acceptance
- cited in PubMed and archived on PubMed Central
- yours - you keep the copyright
Submit your manuscript here:
http://www.chemistrycentral.com/manuscript/

